\title{
2
}

\section{Increasing assertiveness in foreign and economic affairs, 1931-35}

\begin{abstract}
We have adopted European phrases and the ideas that correspond to them. From our childhood we have been accustomed to read, think, and speak of the 'Far East'. It is the Far East to Europe, to the old centres of civilisation, but we must realise that it is the 'Near East' to Australia. ${ }^{1}$
\end{abstract}

- Australian Minister for External Affairs John Latham

With crisis in the Asia-Pacific region and neither Britain nor the US providing adequate security assurances, the Australian government was keenly aware of the need to reorient itself towards its immediate region. It did so with a careful interrogation of the relationships and policy approaches that would facilitate this process. Against the backdrop of the Great Depression and the limited opportunities offered in the British and US markets, trade played a key role in the genesis of a distinct Australian policy.

As Australia looked to the Asia-Pacific to meet its needs for more diverse markets, Japan emerged as the most promising opportunity. In the wake of the Manchurian Crisis, Australia's trade interests intersected with the nation's diplomatic and security ones. This undoubtedly shaped

1 'Speech by Latham on the Australian Eastern Mission, 6 July 1934', NAA: A981, Far 5 Part 16. 
Australia's response to the Manchurian Crisis and its attempts to convince Britain of the economic and diplomatic importance of cordial relations with Japan.

\section{The Great Depression and Australia's foreign debt}

The Great Depression saw a worldwide contraction of economic output following the US stock market crash in October 1929. Australia's Great Depression experience was consistent with that internationally, with rapidly reduced export volumes, high inflation and unemployment. ${ }^{2}$ The nation's particular challenge during the depression years was foreign debt.

Following World War I, Australia became a 'voracious borrower', relying on overseas loans to cover the costs of repatriating servicemen, interest on its war loans and postwar public building projects. ${ }^{3}$ The majority of the Australian government's loans were issued by the City of London. In the years 1923-29, Australia was responsible for more than onequarter of London's total oversees issues. ${ }^{4}$ When the depression hit, Britain and the US ceased lending and called in existing loans, leaving Australia to fund its debt on export income alone. The combined forces of decreased global demand and a sharp drop in the price of Australia's principal exports led to the reduced volume and value of exports. ${ }^{5}$ While the Australian Labor Party (ALP) government of James Scullin drastically reduced imports through increased customs duties, these measures proved woefully inadequate to cover overseas debt repayments. ${ }^{6}$ By early 1931 ,

2 Unemployment in Australia reached its peak at 30 per cent in 1932. Official Year Book of the Commonwealth of Australia, No. 30 (Canberra: Commonwealth Government Printer, 1937), 589.

3 Boris Schedvin, Australia and the Great Depression: A Study of Economic Development and Policy in the 1920s and 1930s (Sydney: Sydney University Press, 1970), 96; Bernard Attard, 'Financial Diplomacy', in Between Empire and Nation: Australia's External Relations from Federation Until the Second World War, eds Carl Bridge and Bernard Attard (Melbourne: Australian Scholarly Publishing, 2000), 93-4, 96-100.

4 Attard, 'Financial Diplomacy', 100.

5 Schedvin, Australia and the Great Depression, 28-9, 110-14.

6 Tim Rooth, 'Ottawa and After', in Between Empire and Nation: Australia's External Relations from Federation Until the Second World War, eds Carl Bridge and Bernard Attard (Melbourne: Australian Scholarly Publishing, 2000), 110-11; Attard, 'Financial Diplomacy', 100-2. 
with export stagnation, a near exhaustion of the country's reserves and an exchange rate already under pressure, Australia looked set to default on loan repayments to London. ${ }^{7}$

Australia was able to avoid default by departing from the gold standard and devaluing against the sterling in June 1931, which allowed the nation to export gold reserves to service overseas debt. The nation's position was also helped by a temporary postponement on war debt repayments owed to Britain and the US. The British government departed from the gold standard the following September and the Commonwealth Bank of Australia, Australia's central bank, set a fixed exchange rate according to the pound sterling ( $A £ 1.25$ to $£ 1$ sterling). ${ }^{8}$ The departure from the gold standard and the 1932 Ottawa Agreements, which is detailed below, formalised a pre-existing arrangement predicated on the preferential treatment of British capital, migration and trade within the Empire. This was known as the Sterling Area. Members of the Sterling Area pegged their exchange rates to the pound sterling, conducted trade in sterling and stored their currency reserves in London. The Sterling Area codified a structural reliance on Britain and its economic performance, as a contraction in the British economy and devaluation would, in turn, devalue the currency of all the Sterling Area members. In this way, a strong British economy and currency became a shared interest within the Sterling Area. ${ }^{9}$

7 The New South Wales Premier, the ALP's Jack Lang, did default on interest repayments in 1931. This was part of Lang's policy response to the Great Depression, in which he called on the British government to temporarily suspend interest payments to British bondholders and reduce the interest rate on Australian government debt repayments. Lang argued that these measures would allow domestic expenditure to be prioritised. The federal government was forced to cover New South Wales's repayments. In January 1932, when Lang announced that he would again default on interest repayments in London, the newly elected United Australia Party passed the Financial Agreement Enforcement Act, which gave the federal government new powers to take control of state revenue. Lang withdrew more than $£ 1$ million in state revenue and instructed public servants not to pay state revenue into the federal Treasury, so as to deprive the federal government of New South Wales's revenue. The New South Wales Governor-General found Lang's actions illegal, and he was subsequently dismissed. The Lang case is significant not only in terms of state-federal government relations, but also in highlighting the Australian government's support for imperial fiscal policy. David Meredith and Barrie Dyster, Australia in the Global Economy: Continuity and Change (Melbourne: Cambridge University Press, 1999), 132-4.

8 Schedvin, Australia and the Great Depression, 238-9; Attard, 'Financial Diplomacy', 101-3.

9 Drummond, The Floating Pound and the Sterling Area, 3-7, 10, 258-61. 


\section{Opportunities in the imperial and US markets}

Australia's ability to continue servicing its overseas debt repayments and recovery from the depression relied on increased export margins. Britain was by far the most important market for Australian goods. In the first two years of the Great Depression, as the rest of the world adopted protectionist measures, Britain remained committed to free trade. As the economic crisis continued, however, key British industries began to struggle. For instance, from 1929 to 1932, coal and steel production fell by 20 per cent and 45 per cent, respectively. ${ }^{10}$ As the British government faced increasing unemployment and a growing trade imbalance, it became clear that free trade was an unsustainable approach. ${ }^{11}$

The 1932 Imperial Economic Conference, held in Ottawa, Canada, was convened in response to the economic challenges presented by the Great Depression. The proposed solution was greater intra-empire trade through a system of reciprocal preferential tariffs, ratified in the Ottawa Agreements. Under the Ottawa Agreements, Britain abandoned threequarters of a century of free-trade policy with the introduction of high import tariffs for foreign goods. The dominions received free entry into the British market and a margin of preference compared with similar foreign producers on certain exports. In return, the dominions extended preferential margins to British goods and granted domestic competitor status to British manufacturers, meaning tariffs would be reduced 'to give United Kingdom producers full opportunity of reasonable competition' with domestic producers. ${ }^{12}$ The Ottawa Agreements were, as a young James Plimsoll, future secretary of the DEA, argued, an 'economic alliance by the Empire against the rest of the world'. ${ }^{13}$

10 Kennedy, The Rise and Fall of British Naval Mastery, 317.

11 Francine McKenzie, 'Imperial Solutions to International Crises: Alliances, Trade and the Ottawa Imperial Economic Conference of 1932', in The Foreign Office, Commerce and British Foreign Policy 1900-2000, eds John Fisher, Effie G.H. Pedaliu and Richard Smith (London: Palgrave Macmillan, 2016), 167, 171, 173-4.

12 Ian M. Drummond, Imperial Economic Policy, 1917-1939: Studies in Expansion and Protection (London: Allen \& Unwin, 1974), 31; 'Report on the Imperial Economic Conference, Ottawa, 1932', in Department of Trade and Customs: International trade relations files, multiple number series [Main correspondence files series of the agency], 1925-56, NAA: A1667, 430/B/18.

13 James Plimsoll, 'Australia and Ottawa', The Australian Quarterly 13, no. 4 (1941): 14-21, at pp. 14-16. 
The Ottawa Agreements offered a solution to the immediate challenges of the Great Depression; however, they were only a partial solution-one that Francine McKenzie describes as a 'defensive response to long-term decline.${ }^{14}$ In relying on protectionist measures and the imperial markets, the Ottawa Agreements simply masked Britain's decline, rather than addressing the structural weakness in the nation's economy. Moreover, imperial preference restricted Britain's market access, irritating other nations and complicating trade relationships. ${ }^{15}$ While imperial preference did aid Britain in its recovery from the Great Depression, it also marked the nation's waning economic capacity and three decades of reliance on the Sterling Area and imperial markets to mask this decline.

The Australian government recognised both the benefits and the limitations of the Ottawa Agreements and economic dependence on Britain. The concessions won by Australia in the negotiation of the Ottawa Agreements included free entry within the Sterling Area for a great number of Australian exports and increased import tariffs on foreign competitor beef and dairy. When Prime Minister Joseph Lyons first discussed the agreements in the House of Representatives, he predicted not only increased exports to Britain, but also the building of 'the strongest economic unit that history has ever known'. ${ }^{16}$

The imperial preference did promote intra-empire sales, contributing to an overall increase in the volume of Australian exports to Britain, rising from 49.79 per cent in the 1931-32 financial year to 52.23 per cent in 1934-35. However, this growth was inconsistent and relatively conservative. Moreover, the Ottawa Agreements restricted any future trade agreements with non-empire nations, stipulating that they could not interfere with the imperial preference. ${ }^{17}$ This constrained Australia's opportunities in foreign markets, as the nation was left with little scope to offer other countries greater access to its market. Minister for Commerce F.H. Stewart was sceptical of the limited opportunities offered in the Ottawa Agreements. He argued that the depression and the need for protectionism had revealed that 'the Empire markets are not limitless in

14 McKenzie, 'Imperial Solutions to International Crises', 167.

15 Drummond, Imperial Economic Policy, 1917-1939, 280-4.

16 CPD: Representatives, 31 August 1932, No. 35, 26, 29.

17 'Report on Imperial Economic Conference, 1932', NAA: 1667, 430/B/18. 
their capacity' and dependence on them was unsustainable. Accordingly, Stewart believed 'foreign trade must be fostered and increased if we are to regain our former standard of living. ${ }^{18}$

Table 2.1 Australian exports to Britain as a percentage of total exports, 1931-32 to 1938-39

\begin{tabular}{|l|l|}
\hline Fiscal year & Percentage \\
\hline $1931-32$ & 49.79 \\
\hline $1932-33$ & 47.66 \\
\hline $1933-34$ & 47.78 \\
\hline $1934-35$ & 52.23 \\
\hline $1935-36$ & 49.54 \\
\hline $1936-37$ & 49.50 \\
\hline $1937-38$ & 55.52 \\
\hline $1938-39$ & 54.52 \\
\hline
\end{tabular}

Sources: Official Year Book of the Commonwealth of Australia, No. 26 (Canberra: Commonwealth Government Printer, 1933), 238; Official Year Book of the Commonwealth of Australia, No. 28 (Canberra: Commonwealth Government Printer, 1935), 258; Official Year Book of the Commonwealth of Australia, No. 33 (Canberra: Commonwealth Government Printer, 1940), 775.

The US was also a significant market for Australian purchases. Where the imperial markets offered opportunities for growth, limited as they were, opportunities in the US were stagnant. Australian-US trade relations date back to the late eighteenth century when the Pacific Ocean was a prominent area for fishing and US merchant ships made port at the newly founded colonies in Australia. Historically, Australia bought far more from the US than it sold in return, the key reason being the two nations' similar exports. Both Australia and the US were primary industry exporters, with raw materials from the mining and agricultural sectors dominating overseas sales. Unlike Australia, the US also had an established secondary industry. Unable to produce its own manufactured goods, Australia developed an immense trade imbalance with the US, at a ratio of approximately $6: 1 .^{19}$

18 F.H. Stewart, 'Australian Commercial Representation Abroad', in Australian Foreign Policy, 1934, eds H. Dinning and J. Holms (Melbourne: Melbourne University Press for Australian Institute of International Affairs, 1935), 11.

19 Raymold A. Esthus, From Enmity to Alliance: US-Australian Relations, 1931-1941 (Melbourne: Melbourne University Press, 1964), 6-8, 13; Official Year Book of the Commonwealth of Australia, No. 26 (1933), 235-9. 
The Great Depression exacerbated Australian-US trade tensions. In June 1930, the Smoot-Hawley Tariff Act was signed into law in the US. The Smoot-Hawley Tariff was designed to combat the falling value of US imports and protect against foreign competition. The Act raised import duties on more than 20,000 goods, with an average increase of 40 per cent. The agricultural sector was granted particularly high tariffs in response to the sharp decline globally in the price of agricultural goods. The US tariff on Australian wool - the nation's principal exportincreased from an already high 31 cents per pound to 34 cents per pound. ${ }^{20}$ Combined with Australia's existing trade imbalance with the US, the new tariff rates sparked acrimony within Australian political and commercial circles. The Daily Commercial News and Shipping List, for instance, argued that the new higher tariffs would make the balancing of Australian trade with the US an impossibility. The paper pondered whether 'Hawley and Smoot, the two gentlemen responsible for the new Tariff ... are altogether devoid of any sense of proportion'. ${ }^{21}$ The Australian Association of British Manufacturers was particularly vociferous in its criticism of the SmootHawley Tariff and Australia's longstanding trade deficit with the US, proposing a boycott against the nation. ${ }^{22}$

The protectionist measures of the Smoot-Hawley Tariff and the Ottawa Agreements contributed to a reduced volume of two-way trade between Australia and the US. However, as Australia still relied on the US for manufactured goods, the adverse ratio of $6: 1$ remained relatively consistent throughout the depression.

Faced with the embarrassment of an ongoing trade imbalance, the Australian government sought to better position its trade in the US market. In June 1934, with the worst of the depression having passed, Lyons presented a draft trade treaty to the US Consul-General in Australia. The treaty tabled lower overall tariff rates and fixed quotas on Australian

20 Esthus, From Enmity to Alliance, 6-8, 13; Richard N. Cooper, 'Fettered to Gold? Economic Policy in the Interwar Period', Journal of Economic Literature 30, no. 4 (1992): 2120-8, at pp. 2122-5.

21 'Australian Imports and American Tariffs', Daily Commercial News and Shipping List, [Sydney], 16 July $1929,4$.

22 Australian Association of British Manufacturers, One-Way Traffic: Australia's Trade with the United States (Melbourne: Australian Association of British Manufacturers, 1931), cited in Harper, Australia and the United States, 124. 
meat, butter and wool. ${ }^{23}$ Lyons' request was subsequently rejected. In the cable detailing this rejection, US Secretary of State Cordell Hull explained that the US was adopting a new framework for world trade premised on 'lessening generally the obstacles to trade' rather than restrictive trade treaties. The Reciprocal Tariff Act, passed in June 1934, was the first significant step towards US tariff reform. The Act gave the US President the power to negotiate bilaterally with foreign powers to reduce tariff duties on a reciprocal basis by up to 50 per cent without reference to Congress. Hull admitted that Australia would benefit little in the early stages of the trade liberalisation program, although he was optimistic that, as the program progressed, 'certain Australian products ... will be placed in a more favourable position'. ${ }^{24}$ In truth, the competing export industries of the two nations meant that, at least until Australia diversified its exports, it would be unlikely to receive any significant benefits from the US trade liberalisation program. ${ }^{25}$ With Australia's traditional markets offering limited opportunities for growth, the government needed to locate new export markets.

\section{Opportunities in regional markets}

Australia's first significant moves towards diversifying its export markets were in 1931. Herbert Gepp, a consultant on economic development to the Prime Minister's Department, was appointed to undertake an investigative mission to the Far East documenting the trade potential in the region. The University of Queensland Senate also commissioned a Far Eastern tour in 1931. A.C.V. Melbourne, Professor of History at the University of Queensland, visited Japan and China, making a comprehensive study of commercial, political and intellectual exchange opportunities.

23 'Doc. 677, Caldwell (US Consul-General in Australia) to Hull (US Secretary of State), 5 June 1934 ' and 'Doc. 679, O'Brien (Chairman US Tariff Commission) to Hull, 10 August 1934', in Rogers P. Churchill, Matilda F. Axton, Shirley L. Landau, N.O. Sappington and Kieran J. Carroll (eds), Foreign Relations of the United States Diplomatic Papers, 1934, General, the British Commonwealth, Volume I (Washington, DC: US Government Printing Office, 1950) [hereinafter FRUS 1934].

24 'Doc. 11, Hull to Caldwell, 15 January 1935', in Rogers P. Churchill and N.O. Sappington (eds), Foreign Relations of the United States Diplomatic Papers, 1935, The British Commonwealth; Europe, Volume II (Washington, DC: US Government Printing Office, 1952) [hereinafter FRUS 1935].

25 Esthus, From Enmity to Alliance, 13-18. 
The final reports of Gepp and Melbourne were markedly similar. Both men found the Asia-Pacific region, with its cheap and large labour force and growing industrialisation, presented immense import and export opportunities for Australia. ${ }^{26}$ Gepp concluded that, by virtue of these opportunities and Australia's proximity, the nation's future political and economic outlook would be influenced materially by Pacific affairs. ${ }^{27}$ To advance trading opportunities, both Gepp and Melbourne emphasised the importance of developing Australia's regional reputation, recommending the appointment of trade representatives and a trade delegation visit to the Far East. ${ }^{28}$

The Gepp and Melbourne reports added weight to the voices of those in the Australian press and political circles also calling for the expansion of regional trade linkages. ${ }^{29}$ In February 1933, Stewart, who, it will be recalled, had questioned the limited opportunities in imperial markets, headed the Conference on Eastern Trade. In attendance were representatives from the federal and state governments, the Consuls-General of Japan, China and the Netherlands East Indies (NEI), along with academics and representatives from the chambers of commerce and of manufacturers from across Australia. The attendees agreed that both the empire link and geography must dictate Australia's trade relations. ${ }^{30}$

The Conference on Eastern Trade led to the establishment of the Advisory Committee on Eastern Trade, with federal and state-level divisions, to investigate and promote regional economic opportunities. Melbourne served as chair of the federal and Queensland divisions of the advisory committee (1933-35). In this role, he reiterated the importance of regional

26 Herbert Gepp, Report on Trade between Australia and the Far East (Canberra: Parliament of the Commonwealth of Australia, 1932); A.C.V. Melbourne, Report on Australian Intercourse with Japan and China (Brisbane: Fredrick Phillips, Government Printer, 1932).

27 Gepp, Report on Trade between Australia and the Far East, 63.

28 ibid., 10-11, 13-14; Melbourne, Report on Australian Intercourse with Japan and China, 76, $147-52$.

29 For examples of media commentary on Australia's trade opportunities in the Asia-Pacific, see 'Eastern Export Trade', The Argus, [Melbourne], 8 May 1931, 4; 'Eastern Trade', The Brisbane Courier, 9 February 1933, 10.

30 Shannon L. Smith, 'Towards Diplomatic Representation', in Facing North: A Century of Australian Engagement with Asia. Volume 1: 1901 to the 1970s, ed. David Goldsworthy (Melbourne: Melbourne University Press and Department of Foreign Affairs and Trade, 2001), 70-2; 'Far Eastern Trade', The Australian Worker, [Sydney], 15 February 1933, 11. 
representation and it was on this advice that the federal government passed the Trade Commissioners Act 1933, restoring the Australian Trade Commissioner Service. ${ }^{31}$

The Gepp and Melbourne missions and the Conference on Eastern Trade indicate that, even as the Ottawa Agreements were being delineated, Australia was exploring opportunities outside its traditional markets. In this, there was a tacit acknowledgement that the nation could not depend indefinitely on the Empire for its economic welfare.

\section{Australia's economic and security interests converge on Japan}

In their individual reports, both Gepp and Melbourne paid particular attention to trade opportunities in Japan. Japan's economy remained relatively controlled throughout the Great Depression as a result of its government's decision to devalue the yen in December 1931, which stimulated exports. As exports grew, the Japanese government imposed exchange controls to keep imports from rising too quickly. These measures protected against overproduction, kept unemployment low and ensured a stable and relatively quick recovery. ${ }^{32}$ Japan's recovery was further aided by the nation's organisation and access to a 'practically unlimited supply of cheap labour', allowing goods to be produced efficiently and at a lower cost to consumers. ${ }^{33}$

Japan's efficient and controlled economy provided a relatively safe market in which Australia could expect increasing export opportunities. Furthermore, Japan was chiefly a manufacturing nation, yet it lacked the raw materials required to meet production needs. This provided an unmatched opportunity for Australia as an exporter of primary goods.

Australian wool was in particularly high demand in Japan and came to dominate trade between the two nations. In the 1919-20 financial year, just 4 per cent of Australia's exportable wool was being purchased

31 James Cotton, The Australian School of International Relations (New York: Palgrave Macmillan, 2013), 75-6. The Trade Commissioner Service was established in 1918, only to be abandoned in 1927 after poor results. Following this, Britain assumed control of dominion trade representation.

32 Dick K. Nanto and Shinju Takagi, 'Korekiyo Takahashi and Japan's Recovery from the Great Depression', The American Economic Review 75, no. 2 (1985): 369-74, at pp. 370-2.

33 Melbourne, Report on Australian Intercourse with Japan and China, 11-13, 130-2. 
by Japan. By 1931-32, this had ballooned to almost 25 per cent. ${ }^{34}$ The wool trade with Japan was largely responsible for positioning the nation as Australia's second-best trading partner by $1930-31 .{ }^{35}$ Given the depression had greatly reduced Australia's purchasing power, Japan's affordable manufactured goods, particularly textiles, were in high demand. A mutually beneficial trade relationship appeared to be emerging-one that played a significant role in stabilising Australia's economic position post depression. ${ }^{36}$

Australia's economic opportunities in Japan emerged against the backdrop of the Manchurian Crisis. Despite a longstanding fear of an expansionist Japan, Australia was reluctant to take action on the Manchurian Crisis, adopting a position of impartiality. Rather than a disinterest in international affairs, Australia's response can be better understood in relation to assessments about its economic and defensive interests. ${ }^{37}$

Following Japan's attack on and annexation of the Chinese province of Manchuria, the League of Nations appointed a commission of inquiry to determine the cause of the crisis and how best to remedy it. The commission was headed by the British Earl of Lytton and the report, known as the Lytton Report, was delivered in October 1932. Before the Lytton Report was made public, the situation in Manchuria deteriorated further, as the Japanese Army continued to extend its power and established the puppet state of Manchukuo. The Lytton Report, finding Japan in breach of the Covenant of the League of Nations and the Washington Naval Treaty, recommended the nation withdraw from Manchuria. Japan refused to comply and was condemned by the league as an international

34 I.M. Cumpston, 'The Australian-Japanese Dispute of the Nineteen-Thirties', The Australian Quarterly 29, no. 2 (1957): 45-55, at p. 50; Eric M. Andrews, 'The Australian Government and the Manchurian Crisis, 1931-3', Australian Outlook 35, no. 3 (1981): 307-16, at p. 310.

35 By 1930-31, Japan was purchasing 10.56 per cent of Australia's total exports, at a value of more than £9.5 million annually. Official Year Book of the Commonwealth of Australia, No. 26 (1933), 237-9.

36 Jack Shepherd, Australia's Interests and Policies in the Far East (New York: International Secretariat, Institute of Pacific Relations, 1940), 27-8; Boris Schedvin, Emissaries of Trade: A History of the Australian Trade Commissioner Service (Canberra: Department of Foreign Affairs and Trade, 2008), 46-8.

37 Ruth Megaw, 'The Australian Goodwill Mission to the Far East in 1934: Its Significance in the Evolution of Australian Foreign Policy', Journal of the Royal Australian Historical Society 59, no. 4 (1973): 247-63, at pp. 247-8. 
aggressor. The league also adopted an official policy of non-recognition of Manchukuo. In March 1933, in response to this policy, Japan announced its withdrawal from the league, effective March 1935. ${ }^{38}$

Australia was reluctant to adopt the league's recommended response to the Manchurian Crisis. In addition to non-recognition of Manchukuo, the league had recommended economic sanctions against Japan in the hope this would discourage any further hostile actions. Japan was Australia's second-best trading partner, with exports valued at more than $£ 11.6$ million annually. ${ }^{39}$ This trade was essential to the nation's economic survival, and Australia did not wish to see sanctions introduced that would threaten this lucrative relationship. ${ }^{40}$ The Australian government voiced its disapproval of sanctions in a 1933 cable to Stanley Melbourne Brucewho was serving as Resident Minister in Britain and was appointed High Commissioner later that year-concluding that 'economic sanctions should not be applied or even considered by the Commonwealth Government'. The hope was that Bruce could convince the British that sanctions would be regarded by the Japanese as an act of hostility. ${ }^{41}$

Situated at the centre of empire policymaking, Bruce had access to the most influential individuals and committees. The diplomatic culture of Whitehall in the 1930s was a matter not simply of opportunity, but also of prestige. Bruce embraced this culture, building private and professional relationships with key British figures in the hope of engendering influence. He coupled cordial relations with vigorous diplomacy, regularly attending and speaking at Committee of Imperial Defence (CID) meetings at which he raised issues of importance to Australia. ${ }^{42}$ Official and private papers reveal that Bruce maintained regular correspondence with the Australian Prime Minister, Minister for External Affairs and other key ministers, offering advice on how best to respond to British policy developments. ${ }^{43}$

38 Andrews, The Writing on the Wall, 78-9; “"Actions of the League of Nations in the Sino-Japanese Crisis”, Report by Bruce, 17 January 1933’, NAA: A981, Chin 166 Part 2.

39 Official Year Book of the Commonwealth of Australia, No. 26 (1933), 237. Figures for 1931-32.

40 CPD: Representatives, 9 March 1933, No. 10, 139.

41 'Commonwealth government to Bruce, [n.d. (early 1933)]', NAA: A981, Chin 125 Part 2.

42 P.G. Edwards, 'The Rise and Fall of the High Commissioner: S.M. Bruce in London 1933-1945', in Australia and Britain: Studies in a Changing Relationship, eds A.F. Madden and W.H. Morris-Jones (Sydney: Sydney University Press, 1980), 39, 42-7; Edwards, Prime Ministers and Diplomats, 109-12.

43 Bruce's correspondence and private papers during his time as High Commissioner can be found in Australian High Commission, United Kingdom [London]-Office of the High Commissioner: Official papers and correspondence maintained by Stanley Melbourne Bruce in London, 1932-45, NAA: M2236. 
In the case of the Manchurian Crisis, Bruce lobbied the British government to reject the sanctions against Japan. Fortuitously, Britain, with its own trade interests in Japan, was reluctant to adopt economic sanctions. The proposed sanctions were accordingly voted down due to a lack of support among the league. ${ }^{44}$ Britain did not, however, have reservations about the non-recognition of Manchukuo, adopting this policy in August 1933 despite Australia expressing its apprehension. ${ }^{45}$

The second and more critical factor influencing Australia's response to the Manchurian Crisis was security. As tensions increased in the AsiaPacific region, the British government was forced to acknowledge the inappropriateness of its recent defence planning. In February 1932, the annual defence review of the Chiefs of Staff Committee (COS) was released. The review criticised the 10-year rule and its impact on British armed power, particularly in the Asia-Pacific, where the position was deemed 'about as bad as it could be'. ${ }^{46}$ On the advice of the COS, the 10-year rule was cancelled, in March $1932 .{ }^{47}$ Despite the cancellation, the Australian government was cautioned that the unstable global economic situation would not permit greater defence commitments to the AsiaPacific, with work at the Singapore base continuing but not intensifying. ${ }^{48}$

It is reasonable to conclude that the Australian government's noncommittal approach to the situation in Manchuria was shaped by national security interests. In taking no action on non-recognition of Manchukuo, neither Japan nor China would be offended and, in turn, further antagonism in the region could be avoided. The records of the Australian Parliament and private government correspondence indicate this indeed contributed to Australia's reluctance to take action. In the immediate aftermath of the Manchurian Crisis, the government was cautious when making comments on the situation, so much so that some accused the Lyons government of failing to keep the Parliament fully informed. ${ }^{49}$ Australia's

44 David S. Bird, J.A. Lyons: The 'Tame Tasmanian'-Appeasement and Rearmament in Australia, 1932-39 (Melbourne: Australian Scholarly Publishing, 2008), 37-8.

45 'Officer (External Affairs officer in London) to DEA, 10 August 1933', NAA: A981, Man 7.

46 'COS Annual Review 1932, 23 February 1932, TNA: CAB 4/2', cited in Andrews, The Writing on the Wall, 108.

47 'Cabinet Meeting, 23 March 1932', TNA: CAB 23/70/19.

48 'CID and Standing Defence Sub-Committee Meeting, 28 July 1932', in Records of the Cabinet Office, Committee of Imperial Defence and Standing Defence Sub-committee: Minutes, TNA: CAB 2/5.

49 For instance, see CPD: Representatives, 26 February 1932, No. 8, 413, and 3 March 1932, No. 9, 577. 
Minister for External Affairs, John Latham, was particularly reluctant to make public statements. He simply emphasised his hope for a peaceful solution and avoided placing responsibility on any one nation, arguing that 'it is inadvisable to make any statement in this Parliament concerning the possibility of aggression by a nation which is now friendly to us. ${ }^{50}$

Bruce was present at the League of Nations assembly when the Lytton Report was handed down. In his report to Lyons, he encouraged Australia to 'remain friends of both parties [Japan and China] and strictly impartial', suggesting no statement be made regarding non-recognition of Manchukuo. ${ }^{51}$ The government agreed, emphasising that its particular security interests would be served by a noncommittal approach. A cable Bruce received from his government stressed:

[W]e are anxious not to adopt at any stage any attitude which might commit us to any participation in military etc. action on account of a quarrel between China and Japan in respect to Manchuria. This should be the guiding principle. ${ }^{52}$

Australia postponed action on the league's recommendations, eventually choosing to adopt a position of non-alignment. ${ }^{53}$ Clearly, Australia was tailoring its response to the unfolding crisis in its region that would deliver integrated economic and strategic outcomes.

\section{'The whole of our interests': The 1934 Australian Eastern Mission}

The 1934 Australian Eastern Mission (AEM) was Australia's first diplomatic mission outside the British Empire. What little has been written on the AEM tends to characterise it as the personal venture of Latham and the swansong of his political career, as he went on to retire in September $1934 .{ }^{54}$ Far from an interesting yet ultimately unimportant episode that had 'no lasting impact on Australian policy', the AEM denotes

50 CPD: Representatives, 19 February 1932, No. 7, 142.

51 'Bruce to Lyons, 22 December 1932', NAA: A981, Chin 166 Part 2.

52 'Commonwealth government to Bruce, [n.d. (early 1933)]', NAA: A981, Chin 125 Part 2.

53 Andrews, The Writing on the Wall, 95-7.

54 Megaw, 'The Australian Goodwill Mission to the Far East in 1934', 247-63; Edwards, Prime Ministers and Diplomats, 90-1. 
Australia's appreciation of the relationship between trade, diplomacy and geography and a determination to integrate its distinct regional interests into the imperial outlook. ${ }^{55}$

From March to June 1934, the mission, led by Latham, travelled through East and South-East Asia, visiting China, Hong Kong, Japan, Malaya, the NEI and the Philippines. ${ }^{56}$ While the AEM was promoted as an exercise in goodwill, with newspaper reports couched in the language of a neighbourly 'courtesy call' and extending 'the hand of friendship'-both Lyons and Latham privately contacted the press to request that it be referred to as such — the vested security and trade interests are easily identifiable. ${ }^{57}$ In his preparation for the mission, Latham meticulously studied the nations he would visit, including local politics, customs and how the Australian government's past policies had impacted its neighbours and shaped perceptions of Australia. Latham also cooperated with the British Foreign Office, drawing on its recommendations and knowledge-more extensive than that of Australia's own embryonic DEA-to inform the AEM's itinerary. ${ }^{58}$ The enthusiasm with which Latham approached these activities suggests he was keenly aware of the strategic capital of the AEM.

On his return, Latham made a speech to parliament in which he centred the security imperatives of the AEM. 'The whole of our interests,' he concluded, 'therefore, lie in doing everything in our power to prevent the risk of war in the East from becoming a pulsing reality. ${ }^{259} \mathrm{He}$ expanded on this theme in his detailed report on the mission, which was disseminated widely throughout the government and business sector:

The continent of Australia is actually in the geographical area often described as 'the East'. The risks attendant upon any disturbance of the peace or actual outbreak of war in that region are of the greatest moment to our people ... Accordingly, the maintenance

55 Allan Gyngell, Fear of Abandonment: Australia in the World Since 1942 (Melbourne: Black Inc., 2017), 17.

56 'Eastern Mission, 1934. Arrangements and Documentation', NAA: A981, Far 2.

57 'The Hand of Friendship', The Sun, [Sydney], 19 March 1934, and 'Mission to East', The Courier-Mail, [Brisbane], 24 March 1934, cuttings, both in NAA: A981, Far 5 Part 14.

58 For a detailed analysis of Latham's cooperation with the British Foreign Office, see Michael Kilmister, 'Antipodean imperialist: Sir John Latham, a political biography, 1902 to 1934' (PhD thesis, University of Newcastle, 2018), 235-42.

59 'Speech by Latham, 6 July 1934', NAA: A981, Far 5 Part 16. 
of friendly relations between Australia and our neighbours and, more generally, the maintenance of peace in the East, should be the major objective of Australian foreign policy. ${ }^{60}$

Although not specified, Japan and the situation in Manchuria were likely the focus of Latham's attention. This speculation is confirmed in private government correspondence and Latham's confidential reportsgiven only to Cabinet. While the AEM visited a number of Far Eastern nations, its true purpose can be found in its interactions with Japan. The significance of Japan was apparent from the preparatory stages of the AEM. The Foreign Office advised the Australian government that a visit to China was 'very desirable if Japan is visited'. ${ }^{61}$ Latham supported this advice, however, he was reluctant to commit to an itinerary for China before plans in Japan were confirmed, fearing this would reduce the time spent in Japan. ${ }^{62}$ In the end, Latham spent roughly equal time in China and Japan.

Latham's interest in Japan rested on the situation in Manchuria. Following the League of Nations' condemnation of Japan's actions, the nation was isolated in the international community. As historian Ian Nish argues, the Australian government identified in this isolation an opportunity to promote bilateral relations that were conducive to national interestsnamely, convincing Japan to maintain league membership and stabilise the situation in Manchuria. ${ }^{63}$ During his time in Japan, Latham met with Japan's Minister for Foreign Affairs, Kōki Hirota. The two men discussed Japan's league membership and the historical, political and social aspects of the situation in Manchuria, as Latham sought to understand Japan's view on the matter. ${ }^{64}$

Latham was unable to convince Hirota that Japan should remain in the league and, in the 'Secret Report on the International Position in the Far East', he was markedly candid about the situation in Manchuria. 'It appears to me,' he wrote, 'that the policy of non-recognition of Manchukuo is going to meet increasingly greater difficulties as time

60 'Australian Eastern Mission 1934: Report of Latham, [n.d. (July 1934)]', NAA: A981, Far 5 Part 16.

61 'Bruce to Lyons, 15 December 1933', NAA: A981, Far 5 Part 1.

62 'Latham to Bruce, 9 February 1934', NAA: A981, Far 5 Part 1.

63 Ian Nish, 'Relations with Japan', in Between Empire and Nation: Australia's External Relations from Federation Until the Second World War, eds Carl Bridge and Bernard Attard (Melbourne: Australian Scholarly Publishing, 2000), 132.

64 'Secret Report on International Position in Far East, 3 July 1934', NAA: A981, Far 5 Part 16. 
passes. So far as one can judge there is not the slightest probability that Manchukuo will cease to exist.' Latham went on to offer a possible solution, recommending that

consideration should be given to the possibility of discovering some formula which would enable both Japan and the League to 'save face' and get rid of what threatens to be a permanent source of poison in the relations between Japan and other countries. It is most improbable that any conceivable formula would satisfy any of the Chinese factions, but that could not be helped. ${ }^{65}$

Despite the vagueness of Latham's formula, the implications are clear: he judged Japan to be the priority for Australia's regional policy and it should somehow be accommodated.

Although the Australian government was seeking to tailor a policy to its distinct regional circumstance, it was not seeking to break away from Britain and the Empire. Australia sought to use the imperial framework to meet its regional needs. This goal is evidenced in Latham's emphasis on the significance of the AEM to the Empire. Latham's public report concluded that the mission had contributed to a 'friendly attitude towards Australia ... This atmosphere should greatly assist in the solution of present and future problems'. Latham was conceivably referring to the significance of diplomatic ties in protecting Australia's strategic interests in the AsiaPacific region. He went on to suggest that friendly relations with Japan were 'of value not only to Australia, but also to the British Empire as a whole'. The link between the Asia-Pacific and the role Australia could play there as a member of the Empire was echoed in a remark made by Secretary of State for Foreign Affairs John Simon, whom Latham cited in his final report: '[The AEM] has been of the greatest value to Australia and the British Commonwealth of Nations in promoting good relations with the countries of the Far East. ${ }^{96}$ In this emphasis on shared benefits, Australia was highlighting the significance of the Asia-Pacific region and the need to integrate it into the imperial strategic outlook.

The contributions of the AEM and Latham to Australia's foreign policy thinking and increasing assertiveness within the imperial framework have been largely overlooked in the existing literature. Gregory Pemberton,

65 'Secret Report, 3 July 1934', NAA: A981, Far 5 Part 16.

66 Simon was speaking in the House of Commons. 'Report of Latham, July 1934', NAA: A981, Far 5 Part 16. 
for instance, contends that Latham's interest in the Asia-Pacific differentiated him from his colleagues, precluding many of his proposals from gaining support and going on to shape policy ${ }^{67}$ Both the government's earlier interest in regional economic opportunities and Lyons' efforts at the 1935 meeting of the dominion leaders (Leaders' Meeting) discount Pemberton's thesis. The Leaders' Meeting was organised to coincide with the silver jubilee celebrations of King George V and Queen Mary and was not an imperial conference; Australia's express request for a gathering of this calibre had in fact been rejected ${ }^{68}$ Foreign affairs and defence were, accordingly, given little attention by the British government in preparations for the meeting. For Lyons, however, this being his first overseas trip as prime minister, the Leaders' Meeting was an opportunity for consultation in imperial policymaking. He arrived in London armed with a detailed report on foreign affairs and an agenda including British rearmament and imperial policy towards the mounting unrest in the Far East and Europe. ${ }^{69}$ So seriously, in fact, did the Australian Prime Minister take the Leaders' Meeting that one newspaper reported the nation's delegation was almost equal in size to all the other delegations combined. ${ }^{70}$

During the third session of the Leaders' Meeting, Lyons tabled the Far East and foreign policy as topics for discussion. He requested more information from the British government on its relations with Japan, indicating that the League of Nations' policy towards Manchukuo left him concerned about the prospects for long-term peace in Australia's immediate region. In a plea to restore Anglo-Japanese relations, Lyons offered a solution: 'some sort of pact of security for all the nation's [sic] bordering on the Pacific Ocean'. ${ }^{71}$ Here Lyons was echoing his predecessors Alfred Deakin and William Morris Hughes, who, in 1909 and 1918, respectively, had

67 Gregory Pemberton, 'An Imperial Imagination: Explaining the Post-1945 Foreign Policy of Robert Gordon Menzies', in Menzies in War and Peace, ed. Frank Cain (Sydney: Allen \& Unwin, 1997), 160.

68 'Hankey (CID Secretary and Cabinet Secretary) Diary, 2 October 1934, TNA: CAB 63/66', cited in Bird, J.A. Lyons, 94.

69 '“Report on Foreign Affairs”, Bruce to Lyons, 7 March 1935', in Prime Minister's Department: Correspondence files, annual single number series with occasional ' $G$ ' [General Representations] infix [Main correspondence files series of the agency], 1903-, NAA: A463, 1957/1060.

70 'Lyons' Jubilee Jaunt: London Surprised at Big Retinue', Sunday Times, [Perth], 27 January 1935, 1.

71 'Minutes Third Meeting of Leaders, 9 May 1935', NAA: A981, Imp 135. 
proposed a Monroe Doctrine for the Pacific to be underpinned by US and British security guarantees. ${ }^{72}$ Just as Latham's earlier so-called formula had recommended, Lyons' pact included the recognition of Manchukuo:

Were the Japanese to be allowed to expand in their own area ... and if not, was there not a fear that the Japanese would turn to the Southern Pacific? The question of the recognition of Manchukuo was relevant ... The recognition of Manchukuo would go a long way to remove any feeling of antagonism on the part of the Japanese. ${ }^{73}$

Lyons saw in Japan a threat to Far Eastern security and feared the nation may turn its attention towards Australia. He looked to the Empire for a collective approach to prevent this from eventuating. Lyons' proposal was not taken seriously and was quickly set aside, with British representatives dismissing Manchukuo as 'irrelevant' to the future of Anglo-Japanese relations and other dominion leaders indicating that Manchukuo was a League of Nations matter and not a question for the Empire. ${ }^{74}$

Both the AEM and Lyons' efforts at the 1935 Leaders' Meeting represent an increasing pragmatism in Australian foreign policymaking, as the nation developed an approach distinct to its geographical locality. This approach was underpinned by a desire to shape the imperial framework to deliver regional security outcomes. The imperial response was indicative of Australia's continuing challenge to convince the rest of the Empire of the importance of the Asia-Pacific in strategic planning.

\section{Strategic integration into the Japanese market}

Although the AEM was promoted as an exercise in friendship and goodwill and 'not', as Lyons explained to Bruce, 'in search of trade', trade invariably came into play. ${ }^{75}$ Latham was a supporter of the Ottawa Agreements and the benefits they accrued for Australian exports. He was also candid in

72 'Deakin to Crewe (Secretary of State for the Colonies), 27 September 1909, TNA: FO 800/91/77', cited in Meaney, A History of Australian Defence and Foreign Policy 1901-23, vol. 1, 199; 'Australia to Have a Monroe Doctrine', The New York Times, 1 June 1918, 9.

73 'Minutes Third Meeting of Leaders, 9 May 1935', NAA: A981, Imp 135.

74 ibid.

75 'Lyons to Bruce, 13 December 1933', NAA: A981, Far 5 Part 1. 
his belief that Ottawa need not constrain the development of foreign trade relationships. In a statement in the House of Representatives, Latham remarked that the Ottawa Agreements were 'the first step towards maintaining and extending the most important of all these markets [the imperial market] for the Australian producer'. He went on to share his hopes that agreements 'along the same line' as Ottawa would develop between Australia and foreign nations, concluding:

Without foreign trade, there would be no chance whatever of our maintaining anything approaching our present standard of living. Australia needs her markets overseas. It is important to us that we shall develop and cultivate real and friendly relations with nations that afford markets for our producers of many commodities. ${ }^{76}$

While he acknowledged that intra-empire economic cooperation was valuable, he believed it was 'obvious that our economic destiny ... is already largely and may be determined even more largely in the future by the volume of trade we do with the countries of the East'. ${ }^{7}$

Following the AEM, Latham prepared three confidential reports on Australia's trade interests in the Asia-Pacific. By virtue of Japan's large volume of trade with Australia, there was an entire report dedicated to Australian-Japanese bilateral trade. The nation also featured prominently in the other two reports, which dealt with wool sales and the appointment of Australian trade commissioners. During the AEM's visit to Japan, Arthur Moore, an information officer from the Department of Trade and Customs, met with Saburō Kurusu, the Director of the Commercial Bureau in the Japanese Department of Foreign Affairs. Although it was agreed that no definite decisions would be made, the meeting allowed both men to voice their hopes for future trade relations. Kurusu presented a litany of grievances concerning Australian trade policy and potential solutions. Chief among his requests was the negotiation of a trade treaty and establishment of a direct link with Australia, rather than, as had been the case in the past, a British official acting on the nation's behalf. ${ }^{78}$ While

76 CPD: Representatives, 23 May 1933, No. 21, 1933, 1651.

77 'Speech by Latham, 6 July 1934', NAA: A981, Far 5 Part 16.

78 'Confidential Report on Trade between Australia and Japan, 30 July 1934', NAA: A981, Far 5 Part 16; Schedvin, Emissaries of Trade, 50-3. 
Latham made no specific recommendations for the negotiation of a trade treaty, believing this to be beyond his jurisdiction as Minister for External Affairs, he did note that 'it would be very wise to act promptly'. ${ }^{79}$

The AEM reports and the increasing importance of the Japanese market influenced the Australian government's decision to commence trade treaty negotiations with Japan. ${ }^{80}$ In December 1934, a small Japanese delegation arrived in Australia to negotiate the Treaty of Friendship, Commerce and Navigation. Negotiations opened in February the following year. ${ }^{81}$ The Japanese government identified high tariffs and the imperial preference system as barriers to the export of Japanese goods. Early negotiations accordingly focused on remediating these barriers. ${ }^{82}$ Although the negotiation of a trade treaty appeared to be a natural progression of Australia's expanding economic and diplomatic interests in Japan, as will be seen in Chapter 3, imperial interests complicated this process.

Latham enthusiastically supported the appointment of an Australian trade commissioner in Tokyo with visions of a dual role. ${ }^{83}$ The first role was the more obvious, being a representative of Australian trade interests. For the financial year 1932-33, Japan's purchases from Australia totalled more than $£ 13.9$ million. Australia’s purchases were $£ 3.7$ million in return. ${ }^{84}$ At a ratio of more than 3:1, this was not a sustainable exchange for Japan and Latham reported criticism among the Japanese government and the press concerning the imbalance. He accordingly encouraged greater purchases if Australia wished to maintain, and in time increase, its share in

79 'Confidential Report on Trade, 30 July 1934', NAA: A981, Far 5 Part 16.

80 The Japanese government had initially proposed a trade treaty in April 1932. The Australian government, however, postponed action until after the upcoming Imperial Economic Conference. The Ottawa Agreements ultimately limited action on bilateral trade treaties with foreign nations and the treaty discussions with Japan were set aside. 'Confidential Report on Trade, 30 July 1934', NAA: A981, Far 5 Part 16.

81 CPD: Representatives, 12 December 1944, No. 50, 1077.

82 'Australia and Japan Seek Trade Treaty', Far Eastern Survey 4, no. 11 (1935): 86-7; “'Draft Treaty of Commerce and Navigation between Japan the Commonwealth of Australia", Memorandum by Abbott (Comptroller-General Department of Trade and Customs) to Prime Minister's Department, 7 February 1935', NAA: A981, Trad 68 Part 2.

83 'Confidential Report on Appointment of Trade Commissioners, 20 July 1934', in Prime Minister's Department: Papers collected in the offices of the Secretary and the Prime Minister, 190139, NAA: CP290/1, 10; 'Broadcast Address of Leader of Australian Eastern Mission, Rt Hon. J.G. Latham, during his visit to Japan, 15 May 1934', in D.B. Copland and C.V. Janes (eds), Australian Trade Policy: A Book of Documents (Sydney: Angus \& Robertson, 1937), 257. Trade commissioners were also dispatched to China and the NEI.

84 Official Year Book of the Commonwealth of Australia, No. 28 (1935), 255, 257. 
the Japanese market. The appointment of a trade commissioner in Tokyo would aid this process, as they could report to the government on bilateral trade opportunities and act as an advocate for Australian exports in the Japanese market. ${ }^{85}$

Latham also believed a trade commissioner could assume the role of a quasi-diplomat. The trade commissioner posting would provide a permanent link between Japan and Australia. Latham emphasised the significance of a quasi-diplomatic role in view of the powerful influence' of the Japanese press, which 'plays a big part in forming public opinion'. ${ }^{86} \mathrm{~A}$ trade commissioner could build a rapport with the media, government and public in what Latham described as a 'persistent and tactful ... propaganda' ${ }^{87}$ In this way, Australian policy pertinent to Japan could be immediately clarified, ensuring misunderstanding and potential resentment were avoided. Not only would this diplomatic activity promote Australia's trade interests, it also would improve relations with Japan, theoretically contributing to regional stability and protecting the nation against future hostility.

Latham paid great attention to the character of the man who would be appointed as trade commissioner in Tokyo, detailing the honour and respect bestowed on government officials in Japanese culture. It was, he stressed, imperative someone be appointed who would inspire confidence, trust and friendliness' ${ }^{8}{ }^{88}$ Lieutenant-Colonel Eric Longfield Lloyd, who had served as an advisor and interpreter during the AEM and, significantly, had a background in intelligence, was appointed Australia's first trade commissioner in Tokyo with a personal recommendation from Latham. He arrived in Tokyo in October 1935. ${ }^{89}$

William Macmahon Ball, who worked with Longfield Lloyd in Japan following the nation's defeat in and occupation after World War II, later questioned his suitability for the posting. Macmahon Ball was critical of Longfield Lloyd's Japanese-language skills and believed his knowledge

85 'Report of Latham, July 1934' and 'Confidential Report on Trade, 30 July 1934', both in NAA: A981, Far 5 Part 16.

86 'Report of Latham, July 1934', NAA: A981, Far 5 Part 16.

87 'Confidential Report on Trade Commissioners, 20 July 1934', NAA: CP290/1, 10.

88 'Confidential Report Appointment of Trade Commissioners, 20 July 1934', NAA: CP290/1, 10.

89 Nish, 'Relations with Japan', 133. 
of Japan to be 'exceedingly meagre and unreliable'. ${ }^{90}$ These criticisms aside, Longfield Lloyd approached his dual role with much industry, particularly as a quasi-diplomat. Official dispatches from Tokyo reveal that he established a close working relationship with Japanese officials. As economic historian Boris Schedvin notes, he was particularly 'assiduous in digging out material and making it available to Australian authorities', providing fastidiously detailed reports about the political and economic situation in Japan as it related to Australia. ${ }^{11}$ These reports included strategic insight. For instance, Longfield Lloyd monitored Japan's developments at the Yampi Sound mine in Western Australia, commenting on the likelihood of Japan using economic projects in Australia as a base for an offensive strategy. ${ }^{92}$ From the perspective of Australia - in an unpredictable region and with a desperate need to expand its export markets-economic engagement with Japan could contribute to the nation's economic and physical security.

In addition to trade commissioner appointments, 1935 also saw the DEA undergo a major restructure and receive full administrative autonomy. Previously, the DEA had been presided over by the Prime Minister's Department and the two departments had shared a secretary. In April 1934, as foreign affairs took on increasing significance and required greater resources, the position of Assistant Secretary of the DEA was established and filled by Lieutenant-Colonel William Roy Hodgson. Hodgson had an extensive military background, having served as the Australian Military Forces (AMF) head of military intelligence (1925-34). In this role, he had specialised in military intelligence in the Far East, including the rise of Japan and how Australia could respond to the threat of regional aggression. In November 1935, the DEA gained full administrative autonomy and Hodgson was appointed secretary. ${ }^{93}$

90 'Report to the Prime Minister on a Mission to Japan, 1 September 1947', in W. Macmahon Ball, Intermittent Diplomat: The Japan and Batavia Diaries of W. Macmahon Ball, ed. Alan Rix (Melbourne: Melbourne University Press, 1988), 272-3.

91 Schedvin, Emissaries of Trade, 61. There are numerous dispatch files from Longfield Lloyd. Those most pertinent to his early years as trade commissioner include 'Japan-Australia Trade Relations Dispatches from Trade Commissioner', in Department of Commerce: Correspondence files, multiple number series, 1935-48, NAA: A601, 402/17/28; 'Japan-General File-Part I', NAA: A601, 402/17/15; 'Japan—General File-Part II, NAA: A601, 402/17/2.

92 'Implications of Japanese Southward Expansion Movt', NAA: A601, 402/17/30.

93 Edwards, Prime Ministers and Diplomats, 92-3; W.J. Hudson, Towards a Foreign Policy, 19141941 (Melbourne: Cassell, 1967), 37-8. 
While there is nothing to suggest the AEM or the appointment of trade commissioners influenced the restructuring of the DEA, against the backdrop of these developments, the decision is a marker of Australia's growing attention to foreign affairs and the need for its own professional, if embryonic, diplomatic service.

Australia's activities in the years 1931-35 do not constitute a complete foreign policy; however, they do demonstrate a concerted attempt by Australian policymakers to define the national interest in relation to Australia's unique regional, economic and strategic circumstances. Foresight and keen appreciation of the components of the national interest accordingly emerge. This is a pragmatism that has been largely overlooked and, when it is noted, it is gestured to, rather than unpacked and its development carefully traced, as has been done here. Though the Australian government was developing an increasing assertiveness in foreign and economic policy, there was nothing to suggest this was at the expense of the imperial link. Rather, Australia actively sought to enmesh its region-specific interests within the imperial framework, in an attempt to reshape the outlook of the Empire into one that better served Australia's unique strategic position. Yet, as the next chapter explores, balancing regional and imperial interests was not so easily achieved. 
This text is taken from The Genesis of a Policy: Defining and Defending Australia's National Interest in the Asia-Pacific, 1921-57, by Honae Cuffe, published 2021 by ANU Press, The Australian National University,

Canberra, Australia.

doi.org/10.22459/GP.2021.02 